\title{
New modes of governance in Bavaria's alpine forests: The 'Mountain Forest Initiative' at work ${ }^{\hbar}$
}

\author{
Kathrin Böhling *, Monika B. Arzberger \\ TUM, Chair of Forest and Environmental Policy, Germany
}

\section{A R T I C L E I N F O}

\section{Article history:}

Received 14 May 2013

Received in revised form 15 January 2014

Accepted 16 January 2014

Available online 28 February 2014

\section{Keywords:}

Forest governance

Forest policy

Climate change adaptation

Stakeholders

Local level

Institutions

\begin{abstract}
A B S T R A C T
There is much talk about the need for stakeholder participation and inter-sectoral coordination in forest policy and management. But there is limited understanding about forest agencies' role in the adoption of new governance modes and their contribution to policy delivery. By drawing on a qualitative implementation study of Bavaria's Mountain Forest Initiative in locally-operating forest agencies, the present paper addresses these gaps. The government wants them to establish collaborative arrangements with various stakeholders to facilitate measures for adaptation to climate change in private forests. The cross-case comparison provides detailed empirical insights into distinct sets of activities for making the initiative 'work'. Stakeholder participation gains a firm basis at the local level if forest agencies develop interest in and generate ownership of prospects for collaborative planning, and tailor these to their needs. The study suggests, however, that involvement of local stakeholders in forest planning is not necessarily instrumental for delivery of effective policies, as reliance on the local level entails the risk that the broader picture of initial policy goals gets lost.
\end{abstract}

(c) 2014 Elsevier B.V. All rights reserved.

\section{Introduction}

Over the last decade, the state of Bavaria in Germany has begun experimenting with new modes of governance in forest policy. In a number of pilot programmes, the early involvement of different stakeholders is considered crucial to achieving a number of intended objectives, including the protection of biodiversity, avoidance of natural hazards, and adaptation to climate change. The 'Mountain Forest Initiative' (Bergwaldoffensive) exemplifies this move. It was launched in 2009 by the Bavarian Ministry of Food, Agriculture and Forestry to restore the protective function of the vulnerable alpine forest in light of climate change, and is ongoing until 2014. To achieve this goal and create a general sense of ownership in the process, the Mountain Forest Initiative seeks the involvement of different stakeholders at the local level (e.g., private forest owners, land-use related authorities, hunters, nature conservationists, and tourism associations).

Traditionally, governance refers to the hierarchical relationship between government actors as 'subjects of control', and private or civil society actors as 'objects of control'. The literature on new modes of governance, by contrast, depicts the self-governance of non-state actors, as well as a broader spectrum of institutionalised arrangements (or modes) for 'plurilateral' coordination, including closed and open co-governance in which state actors participate as one type of actor among many (Kooiman, 2003; Mayntz, 2003). The notion of governance

\footnotetext{
is "This article belongs to the Special Issue: Assessing Forest Governance".

* Corresponding author at: Technische Universität München, TUM School of Management, Chair of Forest and Environmental Policy, Hans-Carl-von-Carlowitz Platz 2, 85354 Freising, Germany. Tel.: + 498161714624 .

E-mail address: boehling@tum.de (K. Böhling).
}

modes thus refers to the 'extent to which governmental and/or nongovernmental actors are involved in governing'; i.e. determining who gets what, where, when and how in society (Arnouts et al., 2012: 44; Howlett et al., 2009). In forest policy, the new modes of governance, which range from the international to the local level and include multiple actors and sectors, aim at decentralisation, the introduction and diffusion of market-based instruments, and use of participatory approaches (Secco et al., 2013). Interaction, shared responsibility and inter-sectoral coordination are considered constituting elements of these new governance modes in forestry (Hogl et al., 2008a,b; Secco et al., 2011), thus mirroring trends in the governance of natural resources, namely: (a) the involvement of an enlarged set of actors in order to define and ensure the effectiveness of key measures, and (b) 'procedures to choose and foster desirable states as needed' (Newig and Kvarda, 2012: 29).

The problem with participatory approaches in forestry, however, is in the rhetoric: more participation is seen as 'better' participation, while actual practice tells a different story (Hogl et al., 2008b; Kaeser et al., 2012). These approaches provide 'more opportunities and access to a broader range of stakeholders who may gain increased and legitimate influence on decision-making ... [But] the pre-existing structures, traditional institutions, actor networks and the entrenched patterns of power distribution remain central to the explanation of governance processes, as well as these processes' policy outputs, impacts, and outcomes' (Hogl et al., 2008a: 26-7). Normative accounts of stakeholder participation in forestry thus do not fit reality. The inclusion of different actors in policy processes is organised somehow and does not stand alone outside established settings (van der Arend and Behagel, 2011). Current approaches to the analysis of changing governance modes in 
forest policy and management support this argument of Hogl et al. (2008a) (e.g., Arnouts et al., 2012; Secco et al., 2011; Winkel and Sotirov, 2011), but are of limited use in examining its implication: stakeholder participation in forestry needs to be studied as a process rather than taken as given.

This paper uses recent theories of the new institutionalism in organisation sociology to study how the process of stakeholder participation unfolds at the local level of public forest agencies and contributes to the delivery of effective policies. This focus addresses two research gaps. Firstly, the role of public forest agencies in new modes of governance needs to be clarified. There is general understanding that their mandate has expanded to the management of forests for multiple purposes, which requires both interactions with a wide range of stakeholders and interests, and skills in conflict resolution and inter-sectoral coordination (Cashore et al., 2010; Humphreys, 2004; Krott and Stevanov, 2008). But it is less clear how administrations and their staff adopt participatory approaches to meet this challenge. As in many other countries, Bavaria's forest sector is characterised by 'sticky institutions' (Buttoud et al., 2011; Raitio, 2011), i.e., a traditionally closed, government-centred, expert-based and subsidy-reliant mode of policy planning (Franz, 2010; Schanz, 2002; Suda, 2002). The second contribution relates to the ongoing discussion about the "causal linkages' between the adoption of participatory approaches in natural resource management and their consequences within a given system (Rauschmeyer et al., 2009). Findings from a meta-analysis on the effectiveness of participatory approaches in different fields of environmental policy reveal that networks are opened up for green preferences, and the acceptance of public decisions has increased, which in turn facilitates implementation. However, 'which contextual or process factors make best-practice cases good enough in order to successfully learn from them' is not well understood (Newig and Fritsch, 2009: 210).

The paper is structured as follows: the next section describes the background and specific characteristics of the Mountain Forest Initiative to provide the empirical baseline for development of the analytical framework. The framework explores the sociological notion of 'institutional work'. With this, attention is focused on the distinct activities aimed at making the Mountain Forest Initiative 'work'. The cross-case comparison provides detailed empirical insights into the implementation of participatory approaches by locally-operated public forest agencies in Bavaria's south. Overall, the forest agencies do a great deal in terms of garnering support for their role in protecting the vulnerable Alpine forests, but they show limited interest in questioning their prevalence in forest planning. This may be both instrumental and detrimental for effective policy delivery. The paper concludes by first discussing the conditions for successful implementation of participation in forest governance on a local level, and then detailing the lessons learned as to the salience of administrative behaviour for the effectiveness of participatory approaches in forestry.

\section{The Mountain Forest Initiative}

Bavaria's Mountain Forest Initiative seeks to facilitate adaptation to climate change through silvicultural measures, rejuvenation of tree stands, and re-creation of protective areas in privately-owned and community forests. Bavaria's alpine forest cover is about 250,000 ha, 150,000 ha of which are categorised as protection forests. As indicated in Table 1 , the initiative addresses $43 \%$ of these forests, covering roughly 100,000 ha. The need to adapt alpine forest stands according to the consequences of climate change is undisputed (e.g., Agrawalla, 2007). Sustained stability of these forests is a major concern of Bavaria's six forest agencies in the alpine area, all of which are involved in the Mountain Forest Initiative. The initiative initially provided the agencies with a spending volume of 7.5 million euros for adaptation projects - to be located mainly in the endangered areas of the protective forests and additional personnel for the newly-assigned role of project management. The spending volume increased due to the initiative's prolongation beyond the original time frame of 2009-12.
Table 1

Comparison of distribution of forest ownership in Bavaria.

\begin{tabular}{lll}
\hline & \multicolumn{2}{c}{ Distribution of forest ownership } \\
\cline { 2 - 3 } & Total Bavaria & Alpine Region \\
\hline Federal forests & $2 \%$ & $2 \%$ \\
State forests & $30 \%$ & $55 \%$ \\
Community forests & $10 \%$ & $5 \%$ \\
Private-owned forests & $58 \%$ & $38 \%$ \\
Thereof protection forest (subject to the regulations & $66 \%$ \\
$\quad$ of the Bavarian Forest Law (BayWaldG)) & \\
\hline
\end{tabular}

In principle, there are two main strategies to sustain the protective function of alpine forest stands in the long term. The first of these strategies is forest conversion, in particular the promotion of the three main species (spruce, fir and beech) in a site-adapted mixture. A second strategy involves forest management in order to rejuvenate overage stocks or to improve the age and species distribution of individual stocks (Kölling et al., 2010). The success of both strategies depends on effective game management. The deer population in the alpine region should allow young trees to grow without the need for additional measures such as fences or individual plant protection, as are often used in the lowlands. In steep terrains, such technical measures are very expensive and difficult to maintain (Süß, 2011). But foresters and hunters may differ extremely in their opinions on how many deer a forest can support before additional measures are needed for its rejuvenation. The Mountain Forest Initiative was not tailored specifically to the conflict between forestry and hunting. But as shown below, it was initially seen as a welcomed opportunity to address this age-old conflict.

The ministerial guidelines for the local-level operation of the Mountain Forest Initiative envision the creation of collaborative arrangements to support local forest agencies in their concern for the endangered alpine forest stands. ${ }^{1}$ The guidelines encourage the establishment of multi-stakeholder-based mountain forest steering committees and project-based forums to advise forest agencies in the definition, selection and implementation of measures. Through these guidelines, interest accommodation, the exchange of views and perspectives, and the creation of ownership and acceptance are supposed to take shape. Distinguishing it from other programmes within Bavaria's forest policy, the Mountain Forest Initiative funds projects within distinct areas; i.e., projects always entail more than one forest owner. Through contracts, funding eligibility is made contingent upon forest owners' commitment to help ensure the success of the funded measure. The guidelines further indicate the availability of funds for project management including costs for personnel and training, facilitation, and mediation, and emphasise the forest agencies' central role in drafting plans, consulting with interested groups, and communicating with forest owners.

The Mountain Forest Initiative's guidelines thus provide preliminary answers on 'who' should be involved, and 'how' that involvement should be managed (Shannon, 2006). However, as experience with collaborative resource management in private-owned forests is scarce, details on how to collaboratively engage in forest planning in the Bavarian alpine region are not specified. The initiative compensates for this lack with project management training in a complementary INTERREG project. $^{2}$ In these seven-day trainings, participants learn how to

\footnotetext{
1 To prepare for the implementation of this pilot project, the Ministry of Food, Agriculture and Forestry initiated a working group with participants of the forest offices in the alpine region. The working group was expected to (a) provide recommendations for the practical implementation of (i.e., the guidelines for) the Mountain Forest Initiative, and (b) make suggestions on how to adjust forest subsidies according to the intentions of the Mountain Forest Initiative. Whereas the guidelines were decided upon in 2008, changes in regulations for related forest subsidies have been published in 2010.

2 The INTERREG project 'Protection forest platforms and -forums in Tyrol and Bavaria' started in January 2009 and was concluded in May 2012. It aimed at supporting the formation and establishment of participatory structures and the necessary competences to work within them in Bavarian forest agencies of the alpine region. Beyond such service provision, the INTERREG project allowed for field research on the implementation of the forest initiative at the local level and granted access to interview partners.
} 
facilitate round table meetings with a diverse group of stakeholders, engage in communication strategies to move beyond deadlocked negotiations, and create general awareness of the protective function of mountain forests (Arzberger, 2010; Himmler et al., 2010). ${ }^{3}$

\section{Analytical framework: the 'institutional work' perspective}

Like many public organisations, Bavaria's forest agencies seek to satisfy exogenously-determined needs and expectations, but prefer stable environments (Brunsson, 1989; March and Olsen, 1989). Bavaria's forest reform from 2004/5 exemplifies this tendency. The political decision to separate the management of state forests from law enforcement, provision of advice for the public good, and responsibility for forestrelated subsidies met with much resentment among administrative staff and interested groups - not least because of the budget cuts and restructuring that this reform entailed (Magerl, 2010; Wagner, 2006). The subsequently-created Bavarian state forest company (Bayerische Staatsforsten) performs the former task and is expected to generate profit, whereas the locally-operating forest agencies carry out the latter three tasks, acting at arm's length from Bavaria's Ministry of Food, Agriculture and Forestry.

The forest agencies' preference for conventions, standard operating procedures, and habits is in line with the general view of the new institutionalism in organisation sociology, namely that the behaviour of organisations reflects socially-constructed, taken-for-granted aspects of appropriate conduct; acting according to these tenets promotes organisations' legitimacy and provides them with vital resources (Meyer and Rowan, 1977; March and Olsen, 1989). Over the last decade, this school of thought rediscovered that the appropriateness of organisational conduct is not carved into stone and developed an interest in the notion of 'institutional entrepreneurs', as introduced by DiMaggio (1988): organised and calculative actors with sufficient resources who envision new institutions to realise their interests. This focus has a somewhat puzzling implication, namely that actors become tempted to impose change upon institutions by which they are constrained (Seo and Creed, 2002). The premise is that institutions cannot be changed by will as actors and interests are themselves institutionally constituted. One way to address this puzzle is to look for conditions at the organisational level that increase the likelihood that individuals are able to shape institutions (Battilana and D'Aunno, 2009).

This is where the notion of 'institutional work' comes in. It entails 'a broad vision of agency in relationship to institutions, one that avoids depicting actors either as "cultural dopes" trapped by institutional arrangements, or as hyper-muscular institutional entrepreneurs' (Lawrence et al., 2009: 1). Emphasis on institutional work in forest agencies' organising of stakeholder participation sheds light on their efforts to cope with, tear down, tinker with, or create anew the institutions within which they 'play and which give them their roles, relationships, resources and routines' (Lawrence et al., 2011: 53). The institutional work perspective thus helps in analysing the implementation of the Mountain Forest Initiative in local settings, including 'creative', 'maintaining' and 'disruptive' activities (see Table 2) (Lawrence and Suddaby, 2006). This distinction lays the groundwork for studying the ways in which adoption of the Mountain Forest Initiative in Bavaria's alpine region is playing out in the forest agencies.

Institutional work may lead to the creation of institutions. This process is associated with 'institutional entrepreneurship' (Greenwood and Suddaby, 2006), but can also be related to the role assigned to 'policy entrepreneurs' (Arnouts et al., 2012); for instance when new actors with the intention to alter power relations and interaction rules in previously closed policy networks are introduced at round tables. Sociology's institutionalism in organisation studies points to a number of activities that may be conducive to such entrepreneurship: the

\footnotetext{
3 The training for foresters won the Alpine Protective Forest Price of the Working Committee of Forest Associations in the Alpine States in January 2012 (Arzberger et al., 2012).
}

'defining' or construction of rule systems that confer status and identity to the new actors at the round table, the 'construction of identities' through which a relationship between such new actors and the policy domain in which they are acknowledged as legitimate players is created, 'mimicry' implying the association of new practices with existing sets of taken-for-granted expectations and norms, and 'educating' of the different actors involved in order to provide them with the necessary skills and knowledge to support the new institution.

Participatory approaches in forest policy may also go hand in hand with efforts to maintain an institution such as restoring belief in the superiority of expert-based forest planning. Furthermore, activities may be undertaken to reclaim legitimacy for the local forest agencies in Bavaria, which have lost 'their' forests after the forest reform in 2005, and are still struggling to reposition themselves in relation to other administrations. The agencies may 'enable work' with additional rules to sustain established practices of forest planning, engage in 'deterring' which entails the building up of barriers to prevent change, 'mythologising' to preserve the normative underpinnings of their historical and authoritative role in forest management, or 'embedding and routinising' through actively infiltrating the normative foundations of state forest management in the inter-sectoral coordination that is envisaged with the Mountain Forest Initiative.

Finally, institutional work may also disrupt institutions - especially by those who are not served by existing arrangements, such as the often marginalised nature conservationists in forest management and policy, or foresters concerned with the inadequate rejuvenation of forests and eager to scandalise ineffective hunting regulations. Although difficult to perceive in practical terms, the disruption of related institutions may go hand in hand with the 'disconnecting of sanctions and rewards' from some rule sets or practices by working through the state apparatus in Bavaria's state-monitored game planning, 'disassociating the moral foundations' of nature conservation and hunting from their concrete practices in mountain forests, or 'undermining' their core assumptions and beliefs with counter acts.

The institutional work perspective pays attention to the "sticky institutions' of the forest sector, but it infuses the analysis of the Mountain Forest Initiative's implementation with agency in the more general sense as the ability of agents to act. This helps to examine the process of coping with stakeholder participation within the confines of administrative rationalities and logics, involving multiple actors whose activities may be counter-intuitive, perhaps ending up with unintended consequences (Djelic and Quack, 2003). The institutional work perspective on new governance modes in forestry thus implies that on-theground evidence cannot be narrowed down to an analogy with normative requirements; it facilitates a more differentiated picture than that of 'ideology’ and symbolic change (Brunsson, 1989).

\section{Case selection and empirical approach}

The present analysis explores the salience of local-level administrative behaviour in new modes of governance in forestry. For this end, the institutional work perspective is applied for conducting a cross-case analysis consisting of three forest agencies in southern Bavaria. The three forest agency cases were selected because of their notable differences in uptake and implementation of the Mountain Forest Initiative. As indicated in Table 3, the sum of their activities to make the initiative work is succinctly described as 'initial marginalisation' (Forest Agency A), 'support but failure' (Forest Agency B), and 'strategic use' (Forest Agency C) of the Mountain Forest Initiative.

A typical implementation pattern of the Mountain Forest Initiative at local-level is lacking, and the analysis below shows that this may be partly but by no means exclusively explained by the differences in private and community forest ownership. The greater significance of private and community forest ownership in forest agencies B and C, for instance, went hand in hand with more willingness to endorse the initiative. Yet, the outcomes of this endorsement are rather different. 
Table 2

Categories and activities of institutional work.

\begin{tabular}{ll}
\hline $\begin{array}{l}\text { Institutional work } \\
\text { categories }\end{array}$ & Activities of institutional work \\
\hline $\begin{array}{l}\text { Creative } \\
\text { Maintaining }\end{array}$ & $\begin{array}{l}\text { Defining, construction of identities, mimicry, educating } \\
\text { Enabling work, mythologising, deterring, } \\
\text { embedding and routinising } \\
\text { Disconnecting of sanctions and rewards, disassociating } \\
\text { the moral foundations, and undermining }\end{array}$ \\
\hline
\end{tabular}

Two types of data provide the basis for this implementation study of the Mountain Forest Initiative at the local level of forest agencies: (1) field observations from direct involvement in the Mountain Forest Initiative as process facilitator, and (2) qualitative interviews with the staff of forest agencies in Bavaria's alpine region. The Chair of Forest and Environmental Policy at Technische Universität München (TUM) and the Bavarian State Institute of Forestry (LWF) were commissioned to facilitate and evaluate the Mountain Forest Initiative and report their activities to the Bavarian Ministry of Food, Agriculture and Forestry (Wagner et al., 2012; Suda et al., 2013). The evaluation is based on 13 semi-structured interviews with the heads of all six forest offices, district managers involved in the initiative, and members of the newly created group of mountain forest managers (Wagner et al., 2012). Of these, four were group interviews consisting of 2, 2, 3, and 7 interviewees respectively, which amount in total to 23 interview partners. Of the interviewees, 13 are based on the selected forest agencies. The semi-structured interviews were recorded and transcribed. They revolved around four topics:

$\bigcirc$ Strategy development in the forest agencies with regard to the Mountain Forest Initiative

$\bigcirc$ Administrative responses to the Mountain Forest Initiative

$\bigcirc$ Planning of projects and measures in pilot areas

P Participation in mountain forest steering committees and forums, including procedures for participation, inter-sectoral coordination, and lessons learned

The analysis builds on the insights from the two reports mentioned above. It follows two questions:

1. How did the forest agencies perceive of and relate to the Mountain Forest Initiative when it was introduced to them?

2. How did the Mountain Forest Initiative evolve and take shape at the local administrative level in terms of different institutional work activities?

\section{Analysis: the Mountain Forest Initiative at work}

Table 4 summarises the main findings of the analysis with further detail given in the sections below.

\subsection{Maintaining work: initial marginalisation of the Mountain Forest Initiative}

1. Forest Agency A provides its services to private forest owners in two counties, and employs eight district managers of whom all but one are primarily based in their districts rather than in the central office. The share of privately-owned forests in both counties is relatively

Table 3

Forest ownership in the selected cases. ${ }^{\mathrm{a}}$

\begin{tabular}{lll}
\hline Forest agencies & Private and community forests & Public forest \\
\hline A: 'Initial marginalisation' & $43 \%$ & $57 \%$ \\
B: 'Support but failure' & $59 \%$ & $41 \%$ \\
C: 'Strategic use' & $78 \%$ & $22 \%$ \\
\hline
\end{tabular}

\footnotetext{
a Source: Allgemeines Liegenschaftsbuch Bayern - ALB-Datenbank, accessed 07.05.2010.
}

low, and only one of these contains mountain forests. The Mountain Forest Initiative was therefore perceived by the agency's head as having only limited relevance. A mountain forest committee was not set up and only one project - the building of skid trails - was initiated by the agency in 2009. Once the project area for the only pilot project in existence at the time was set, a second pilot project setting up fences - was initiated by a private forest owner. He became aware of the Mountain Forest Initiative through the ministry's public relations rather than the forest agency's activities.

The opportunity to recruit additional staff was used right from the start, however, and a forester with good knowledge of the local context was employed to act as the mountain forest manager (parttime, $50 \%$ of full-time hours). He received no specific training, was not based in the central office, and was supposed to work in close cooperation with regular staff. His contract ended in December 2011. Thus, once the agency's initial project area was set and a mountain forest manager recruited, it did little by itself to flesh out the initiative's underlying idea of collaborative forest planning. The time and effort needed to do so was considered unavailable.

2. Forest Agency A appeared hesitant in endorsing the Mountain Forest Initiative, and this caution subsequently deterred approval of the Mountain Forest Initiative within the area. The agency's head drew strongly on LWF staff to decide what to do within the initiative. From late 2009 onwards, two telephone conversations were necessary before further support was solicited, including conducting a stakeholder analysis, setting up information events for and encouraging talks with private forest owners, implementing the envisaged projects, and organising field visits. Two information events were organised, which signalled much interest for the Mountain Forest Initiative among private forest owners, mayors, hunters, and nature conservationists. The former, however, were not sufficiently convinced to join in with the initiative. Numerous additional talks were necessary to generate commitment.

In the meantime, a district manager and the recruited mountain forest manager planned for the implementation of measures in the two project areas. Their work involved the joint evaluation of the forest stands, development of silvicultural measures, and allotment. Once the affected private forest owners were identified, the respective mayors were informed about the goals of the Mountain Forest Initiative, the two pilot areas, and the possibility of setting up local forums to support their implementation. Since the demands for silvicultural measures were unlikely to be met without the involvement of the hunting community and farmers with pasture rights, the forum's role in easing communication was considered a priority. In 2010, the district manager participated in the training programme within the INTERREG project. He appreciated the training for learning how to collaborate in the forums and link up project management with day-to-day routines (embedding).

Through project implementation and field visits, merits of the Mountain Forest Initiative became evident. Despite initial reservations, awareness for the potentials of a mountain forest steering committee gained ground. Thanks to the initiative of the above-mentioned district manager and with support from LWF staff, a regional mountain forest committee was set up in autumn 2011. The participants of this committee include the county's chief administrative officer, representatives of the county's offices for water management and road construction, mayors, and representatives of hunting, nature protection, and sport associations. Initiation of an additional road construction project is the designated short-term goal of the committee. Over the long term, it seeks to build a broad alliance in support of the Mountain Forest Initiative and to provide the forest agency with the political support for this and other inter-sectoral projects. Being relatively late in creating a mountain forest steering committee turned out to be an advantage for Forest Agency A: it was able to capitalise upon lessons learned elsewhere and mimicked good practices. 
Table 4

Bavaria's mountain forest initiative at work.

\begin{tabular}{|c|c|c|c|}
\hline & Forest agency A: initial marginalisation & Forest agency B: support but failure & Forest agency C: strategic use \\
\hline $\begin{array}{l}\text { Perception of the Mountain } \\
\text { Forest Initiative }\end{array}$ & $\begin{array}{l}\text { Interesting initiative but lack of time; } \\
\text { willingness to satisfy ministry's demand to } \\
\text { act, yet hesitant endorsement of initiative. }\end{array}$ & $\begin{array}{l}\text { Interesting initiative but time-consuming; } \\
\text { straightforward use of programme guide- } \\
\text { lines to target unresolved forestry-hunting } \\
\text { conflict. }\end{array}$ & $\begin{array}{l}\text { Great initiative; opportunity to realise idea } \\
\text { of collaborative planning at large scale. }\end{array}$ \\
\hline Entrepreneurs & $\begin{array}{l}\text { District manager; (later) chief } \\
\text { administrative officer. }\end{array}$ & $\begin{array}{l}\text { Heads of unit in forest agency; chief } \\
\text { administrative officer. }\end{array}$ & $\begin{array}{l}\text { Agency head with heads of unit and } \\
\text { mountain forest committee. }\end{array}$ \\
\hline Institutional work & $\begin{array}{l}\text { Lack of administrative support deters } \\
\text { assignment of project areas and setting up of } \\
\text { participatory arrangements; project } \\
\text { planning for the Mountain Forest Initiative is } \\
\text { embedded in forest planning routines; late } \\
\text { setting up of forum mimics experiences from } \\
\text { other agencies involved. } \\
\text { MAINTAINING-creative }\end{array}$ & $\begin{array}{l}\text { Initial programme endorsement according to } \\
\text { ministry guidelines (mimicry); use of } \\
\text { initiative to re-address ongoing hunting- } \\
\text { forestry conflict undermines initiative original } \\
\text { intention to foster collaborative planning for } \\
\text { CCA;chief administrative officer's withdrawal } \\
\text { from committee disassociates political } \\
\text { support from participatory governance } \\
\text { creative-disruptive }\end{array}$ & $\begin{array}{l}\text { Co-authoring of initiative at Länder level } \\
\text { (construction); first mover in construction of } \\
\text { new roles and arrangements; extensive use } \\
\text { of training (educating); definition of criteria } \\
\text { for project selection and design of 'partici- } \\
\text { pation standard';standard not sufficient to } \\
\text { generate ownership; additional deliberation } \\
\text { and negotiation necessary (embedding) } \\
\text { creative-maintaining }\end{array}$ \\
\hline Forest ownership (private/public) & $43 \% / 57 \%$ & $59 \% / 41 \%$ & $78 \% / 22 \%$ \\
\hline
\end{tabular}

\subsection{Disruptive work: support but failure of the Mountain Forest Initiative}

1. Compared to Forest Agency A, enactment of the Mountain Forest Initiative is very different in Forest Agency B, as is the share of private forests (namely 59\%). Alpine forest stands are located in two counties. Responsibility for provision of advice to private forest owners in the two counties is divided between the agency's two heads of units. They were also responsible for the implementation of the Mountain Forest Initiative within the agency. They looked at the initiative as a much-needed opportunity for settling the ongoing forestry-hunting conflict. Accordingly, a range of possible project areas was identified in an office meeting of the two heads of unit and the nine district managers. To support the unit heads, two mountain forest managers were recruited (part-time, 50\% of fulltime hours). Once project areas were selected and initial decisions taken, the mountain forest managers were supposed to evaluate the selected areas and suggest specific measures.

2. Further analysis of the Mountain Forest Initiative's implementation in Forest Agency B concentrates on the efforts undertaken to generate political backing for the initiative in one of the two counties. This focus reveals a number of challenges for collaborative planning in forestry. As indicated above, there was agreement inside Forest Agency $B$ that the ministerial guidelines for the operation of the Mountain Forest Initiative in the agencies provide sufficient guidance and do not require additional clarification and interpretation. Support from LWF staff was not considered necessary. Agency B thus mimicked the guidelines and convened an information event in the county to generate broad awareness of the initiative, propose its pre-designed project areas, and set up a mountain forest committee.

Support from local politicians for such a steering committee is considered critical according to the guidelines; however, in the county the opposite happened. The chief administrative officer withdrew from the Mountain Forest Initiative before it actually began and did not join the information event, principally because of the manifest forestryhunting conflict. This disassociation crippled further thinking about inter-sectoral coordination in the Mountain Forest Initiative, as a chief administrative officer would oversee the work of authorities and administrations at the county level including those responsible for nature protection, water management and hunting.

Forest Agency B has put itself at the centre of resolving the forestryhunting conflict instead of letting itself assume the role of one stakeholder among several (i.e., forest owners and hunters) with an interest in joint responsibility for game and habitat. This behaviour undermined the initiative's original intention to foster collaborative planning for climate change adaptation in alpine forest stands. Forest Agency B eventually equated the Mountain Forest Initiative with a timeconsuming and frustrating exercise, and perceived its take on it as a failure. The initiative underwent a drastic turn-around in the agency: Stakeholder participation was narrowed down to information rather than consultation and co-decision. Instead of pushing new projects, a touring exhibition of the Mountain Forest Initiative was designed. The classic advisory repertoire was re-activated and the focus went back to the provision of advice for individual, demand-driven measures.

\subsection{Creative work: strategic use of the Mountain Forest Initiative}

1. Forest Agency $\mathrm{C}$ acts in two counties in which the share of private and community forest ownership is relatively large. In contrast to the other two agencies, Forest Agency $C$ built on previous experience with collaborative planning in forestry when adopting the Mountain Forest Initiative. It was part of a mediation procedure in the early- to mid-2000s that also involved forest owners, representatives from hunting associations and several local administrations, and the mayor of a given municipality, many of whom feared a serious threat of natural hazards because of the endangered status of the nearby protection forest in the mountains. This heterogeneous group, initially far from like-minded, jointly agreed on a set of measures to restore the protective function of the mountain forest through third-party assisted communication and interest accommodation (Müller, 2006). This success story created a legacy in Forest Agency C. Its entrepreneurial head was eager to promote the idea of collaborative planning in Bavaria's forest ministry.

2. The successful outcome of the mediation procedure - i.e., the integrated management of a protection forest - generated momentum in Forest Agency C. Its head and the two heads of unit shared the view that most of forestry is about people, communication and ability to accommodate between different interests in forest management. Contrary to Agencies A and B, this forest agency also articulated the need to reposition itself vis-à-vis other authorities and ministries after Bavaria's forest reform. The head of Agency $C$ therefore moved on and used his contacts in the forest ministry to promote his ideas and call for elaboration of the Mountain Forest Initiative as a state programme from 2008 onwards, i.e., one year before implementation started. Later on in that same year, a fulltime position for mountain forest management was installed, and in 2009 the second full-time position followed. Today, Forest Agency $\mathrm{C}$ employs four mountain forest managers. Moreover, a steering committee was set up even before private forest owners and municipalities were informed of the Mountain Forest Initiative. ${ }^{4}$

\footnotetext{
${ }^{4}$ A deputy chief administrative officer chairs the steering committee.
} 
This first-mover status turned Forest Agency C into a key player when the ministry's guidelines for implementation of the Mountain Forest Initiative were constructed.

Agency $C$ went a bit beyond the guidelines in working with the mountain forest steering committee. As spelled out, the committee was consulted to propose project plans and measures to its participants and inform them about progress on the ground. Here, it was also used as a forum for open discussions about the effectiveness of planned projects and measures in terms of the initiative's goal to adapt alpine forest stands to climate change. Whereas other agencies had meetings with their steering committees about twice a year, Agency $C$ met more often with the committee and invited its participants to join organised field trips to project sites. Furthermore, the committee was involved in development of a public relations campaign for the Mountain Forest Initiative. A PR-agency was commissioned to devise a communication strategy for connecting with people in the respective project areas, and the steering committee's view on their strategy draft was called in before further PR steps were taken. Agency C's various efforts to collaborate with the committee generated a positive atmosphere among stakeholders and ensured political backing for project financing within the Mountain Forest Initiative beyond its original termination in December 2012.

Internally, capacities were strengthened through the extensive use of INTERREG training: the four mountain forest managers and four district managers from Agency $\mathrm{C}$ used this opportunity for education. Once possible project areas had been identified by Agency $C$ and rated according to a pre-defined list of criteria, the forest agency was ready to propose eight project sites to the forest owners. At each of these, measures were supposed to be implemented according to the previously defined 'participation standard' of the agency. This standard entails the following components:

Responsibility for every project area is allocated (to a district manager or mountain forest manager);

The project area is presented to the 'affected' mayor, after which an information event is conducted in the respective municipality for forest owners and interested groups;

$\bigcirc$ Once the information event has taken place, a local mountain forest forum is set up with the involvement of elected stakeholders to represent their respective groups;

The forum has three meetings, at which the following should happen:

(a) information and exchange, after which the distinct stakeholder groups meet individually for opinion making;

(b) joint discussion and development of project-related suggestions; and

(c) after another external round of opinion making and interest accommodation, a list of feasible measures is defined, and implementation can start.

According to this standard, the forest agency's 'offer' to invest public funding in a distinct project area is collected if a given forum cannot achieve agreement. In practice, however, the three-step approach was far too top-down; it did not provide sufficient space for views and concerns that arose from the bottom up. Additional time for deliberation and negotiation was needed to generate broad ownership in proposed projects (embedding). Forest owners did not necessarily share the agency's problem views on 'endangered' protection forests. And sometimes, agency staff refrained from dealing with the conflictive game management issue. Agency $C$ tried to settle this issue by drawing on external expertise: a game biologist was commissioned to develop a hunting concept. Doing so helped to objectify the forestry-hunting conflict. But it did not relieve the agency from the task of coping with conflictive values and worldviews and suggesting ways to move beyond deadlock.

\section{Discussion}

The cross-case analysis indicates that mountain forest management in Bavaria turns into an arena for the endorsement of stakeholder participation if the locally-operated forest agencies develop an interest in and generate ownership of prospects for collaborative planning, and tailor these to their needs. Conditions for collaborating with enlarged actor networks have to be constructed and defined at local levels, building upon support from key actors in both the agencies and local politics. Creative efforts end up in frustrating disruptions or run the risk of turning into symbolic change if they are not linked with the routines of forest staff and potential beneficiaries. Perhaps the most important finding of the analysis is that combinations of maintaining and creative activities are essential for making the Mountain Forest Initiative work - 'work' in the sense of generating positive outcomes like the acknowledgement in politics and society of forest agencies' critical role in the provision of stable forest ecosystems as a public good. Such combinations include the embedding of the initiative in the forest agencies' routines whereby the laggard (Agency A) differs from the first mover (Agency $C$ ) in employing a narrow rather than a broad set of creative activities.

Although they came from two different angles, both Forest Agency A and Forest Agency $C$ made sure to always control the process of stakeholder participation in the Mountain Forest Initiative. The response of Agency A to the initiative may be described as creeping compliance with the federal demand for stakeholder participation in forest management. The initiative's potential to establish collaborative planning was initially marginalised, but has slowly but surely moved centre stage with the building of broad support for the creation of an ambitious steering committee involving different stakeholders. Forest Agency C, by contrast, garnered political support for the initiative, developed internal capacity, and pre-defined possible project areas and a procedure for local-level participation before entering discussions with forest owners, municipalities, mayors and interested parties about concrete measures. This state of preparedness allowed Agency $C$ to use the Mountain Forest Initiative strategically and expand its authority in planning for vulnerable alpine forests.

Forest Agency B failed with its take on the Mountain Forest Initiative, and this paper's analysis of institutional work helps explaining why. The office's straightforward use of the initiative to re-open the debate on the age-old forestry-hunting conflict and put it on top of the agenda by simply mimicking the ministry's guidelines and taking them at face value was disruptive. Rather than taking the lead in the overall process, Agency B allowed a chief administrative officer to become dominant, which nurtured further politicisation of the initiative. Agency B did not develop ownership in the initiative and perceived it as a timeconsuming and rather disrupting experiment. The agency may have remedied this frustrating outcome if it would have used the political withdrawal from the initiative as an opportunity to restore belief in its capacity to steer forest planning. Apparently, however, such maintaining moved out of focus once the disruptive activities had gained momentum.

Hence, which lessons can be drawn for assessment of new forest governance on a local level from implementation of the Mountain Forest Initiative in Bavaria's south? The present study provides evidence for the assumption of Secco et al. (2013) that local-level forest agencies play key roles as linkage bodies in collaborative resource management: horizontally by facilitating cooperation between different stakeholders, and vertically by translating federal demands for climate change adaptation in forest ecosystems to local contingencies. The institutional approach reveals that an effective blueprint for joint forest planning and hence a shift away from the individual-owner focused advisory repertoire does not exist. Forest agencies should not risk relying solely on guidelines that were invented at higher levels. Rather, emphasis needs to be placed on making stakeholders join in when planning for collaborative projects in the forest. The good news is: this innovative step 
should not be done from scratch. The bad news is that higher levels may find it difficult to cope with the local-level feedback loops that result from needed flexibility, experimentation and contested processes. Any endorsement of participatory approaches in forest policy by Bavaria's responsible ministry and acknowledgement of its transformative potential are (still) out of sight.

\section{Conclusion}

New modes of governance in forest policy and management can and perhaps should be conceived as processes whose dynamics may be counter-intuitive and/or fragile, yet contingent upon the sticky institutions of this field. The present analysis reveals the stickiness of the traditional planning approach in Bavaria's forest agencies. According to the traditional planning approach, agencies define problems, design a set of measures to cope with these, and then inform or consult with affected groups like private forest owners on whose land such 'problems' are identified. Participatory planning brings in stakeholders at an early stage, ideally when the problem view is defined. Neither of the agencies described above nor any of the other three involved in the Mountain Forest Initiative leaned towards participatory planning (Wagner et al., 2012). They continued to hold the pen when drafting measures and suggesting project areas, showing limited interest in having their expertise and its perceived primacy in forest planning questioned.

Simultaneously, however, it has become commonplace to communicate with the public, conduct information events, bring in stakeholders to implement joint projects, and ensure these projects' feasibility and broad commitment. The momentum that this created turns a select number of Bavaria's forest agencies into authorities that are accountable to society. The latter's consequences for the total of 47 forest agencies in Bavaria may be disputed. Yet indications of the Mountain Forest Initiative's impact on policy-makers in Bavaria are discernible. Today, ex-post monitoring and performance evaluation of stakeholder participation are institutionalised in the forest ministry through the creation of a new role and its assignment with new staff. Moreover, the ministry commissioned a study in 2012 which builds on the Mountain Forest Initiative, and seeks to establish and mainstream 'Participation as a communicative strategy in the forest administration. ${ }^{5}$ There is certainly much talk now about stakeholder participation in Bavarian forest policy and management. And, interestingly, this talk has a firm basis at the local level.

Stakeholder participation is critical for climate change adaptation in alpine forest stands, as it helps to cut across established boundaries (Newig and Fritsch, 2009). However, reliance on the local level for the functioning of participatory approaches entails the risk that the broader picture of initial policy goals may get lost. If forest governance becomes 'plurilateral' - i.e., if stakeholders network around specific issues and engage in shared decision-making for the arrival at voluntary agreements - government actors are challenged to assume a central role in these networks and become instrumental in the production of public goods (Howlett et al., 2009). The present analysis provides evidence for their (i.e. the forest agencies') centrality: professionals with legal status determine forest planning, network formation is directed and rules are deployed to increase the bindingness of agreed decisions. Yet, the effectiveness of adopted measures may be questioned if the local level largely determines them. A mixture of old (hierarchical) and new (plurilateral) modes of governance across multiple levels and loosely coupled arenas seems to be critical for the delivery of effective measures in forest policy (Hogl et al., 2008a). Future research should therefore pay more attention to multi-level coordination in forest governance and study how hierarchy, negotiation and competition in

\footnotetext{
${ }^{5}$ English translation of the official project title: "Partizipation als kommunikative Strategie der Forstverwaltung". See: [http://www.wup.wi.tum.de/index.php?id= $122 \& \mathrm{~L}=0$ ] (accessed 07.11.2013).
}

addition to information exchange and learning contribute to the delivery of effective policies.

\section{References}

Agrawalla, S., 2007. Klimawandel in den Alpen: Anpassung des Wintertourismus und des Naturgefahrenmanagments. OECDPublishing.

Arnouts, R., Zouwen van der, M., Arts, B., 2012. Analysing governance modes and shifts governance arrangements in Dutch nature policy. For. Policy Econ. 16, 43-50.

Arzberger, M., 2010. Runde Tische für den Bergwald. Zeitschrift des Bayerischen Gemeindetags, 2/2010, pp. 63-65.

Arzberger, M., Wenske, C., Binder, F., Suda, M., 2012. Zertifizierte Prozessbegleiter für den Bergwald. Partner aus Tirol und Bayern bilden Prozessbegleiter für Beteiligungsverfahren im Schutzwaldmanagement aus. LWF aktuell 88, 52-54.

Battilana, J., D'Aunno, T., 2009. Institutional work and the paradox of embedded agency. In: Lawrence, T.B., Suddaby, R., Leca, B. (Eds.), Institutional Work. Actors and Agency in Institutional Studies of Organizations. Cambridge University Press, Cambridge.

Brunsson, N., 1989. The Organization of Hypocrisy: Talk, Decisions and Actions in Organizations. John Wiley \& Sons, Chichester.

Buttoud, G., Kouplevatskaya-Buttoud, I., Slee, B., Weiss, G., 2011. Barriers to institutional learning and innovations in the forest sector in Europe: markets, policies and stakeholders. For. Policy Econ. 13, 124-131.

Cashore, B., Galloway, G., Cubbage, F., Humphreys, D., Katila, P., Levin, K., Maryudi, A., McDermott, C., McGinley, K., 2010. Ability of institutions to address new challenges. In: Mery, G., Katila, P., Galloway, G., Alfaro, R.J., Kanninen, M., Lobovikov, M., Varjo, J. (Eds.), Forests and Society - Responding to Global Drivers of Change, 25. IUFRO, pp. 441-485 (World Series).

DiMaggio, P., 1988. Interests and agency in institutional theory. In: Zucker, Lynne G. (Ed.), Institutional patterns and organizations. Culture and enviroment, Mass.: Ballinger Pub. Co., p. 3-21.

Djelic, M.-L., Quack, S., 2003. Theoretical building blocks for a research agenda linking globalization and institutions. In: Djelic, M.-L., Quack, S. (Eds.), Globalization and Institutions. Redefining the Rules of the Economic Game. Edward Elgar, Cheltenham.

Franz, T., 2010. Forstverwaltungssysteme. Verlag Kessel, Remagen.

Greenwood, R., Suddaby, R., 2006. Institutional entrepreneurship in mature fields: The big five accounting firms. Academy of Management Journal 49 (1), 27-48.

Himmler, D., Arzberger, M., Hamberger, J., 2010. Wenn Förster im Berg- und Schutzwald moderieren müssen. AFZ-Der Wald, 20/2010, pp. 8-9.

Hogl, K., Nordbeck, R., Pregernig, M., 2008a. GoFOR - new modes of governance for sustainable forestry in Europe. Final Activity Report of EU funded project no. 6447GoFor (16.09.2008).

Hogl, K., Nordbeck, R., Pregernig, M., 2008b. New modes of governance: programmatic rhetoric and actual practices. GAIA 17 (4), 399-401.

Howlett, M., Rayner, J., Tollefson, C., 2009. From government to governance in forest planning? Lessons from the British Columbia Great Bear Rainforest Initiative. Forest Policy and Economics 11 (5-6), 383-391.

Humphreys, D., 2004. National forest programmes in Europe: generating policy-relevant propositions for formulation and implementation. In: Humphreys, D. (Ed.), Forests for the Future - National Forest Programmes in Europe. Country and Regional Reports From COST Action E19. Office for Official Publications of the European Communities, Luxemburg, pp. 13-43.

Kaeser, A., Bernasconi, J., Zimermann, W., 2012. Governance approaches in Swiss forest biodiversity policy: do they really work? For. Policy Econ. http://dx.doi.org/10.1016/ j.forpol.2012.07.010.

Kölling, Ch., Beinhofer, B., Hahn, A., Knoke, T., 2010. Wie soll die Forstwirtschaft auf neue Risiken im Klimawandel reagieren? AFZ-Der Wald, pp. 18-22.

Kooiman, J., 2003. Governing as Governance. Sage, London.

Krott, M., Stevanov, M., 2008. Comprehensive comparison of state- and forest institutions by a causative benchmark-model. Allg. Forst. Jagdztg. 179 (4), 57-63.

Lawrence, T.B., Suddaby, R., 2006. Institutions and institutional work. In: Clegg, S.R., et al. (Eds.), The Sage Handbook of Organization Studies. Sage, London.

Lawrence, T.B., Suddaby, R., Leca, B., 2009. Introduction: theorizing and studying institutional work. In: Lawrence, T.B., et al. (Eds.), Institutional Work. Actors and Agency in Institutional Studies of Organizations. Cambridge University Press, Cambridge.

Lawrence, T.B., Suddaby, R., Leca, B., 2011. Institutional work: refocusing institutional studies of organization. Organ. Stud. 20 (1), 52-58.

Magerl, F., 2010. Bilanz der Forstreform. Response to Interpellation of Green Party. Bavarian Parliament (Bayerischer Landtag), Munich (6 pp.).

March, J.G., Olsen, J.P., 1989. Rediscovering Institutions. The Organizational Basis of Politics. The Free Press, New York.

Mayntz, R., 2003. New challenges to governance theory. In: Bang, H. (Ed.), Governance as Social and Political Communication. Manchester University Press, Manchester, New York.

Meyer, J.W., Rowan, B., 1977. Institutionalized organizations: formal structure as myth and ceremony. Am. J. Sociol. 83 (2), 340-363.

Müller, G., 2006. Vom Konflikt zum kooperativen Handeln. Mit Umweltmediation zum integralem Schutzmanagement. Approved Dissertation Technische Universität München (TUM).

Newig, J., Fritsch, O., 2009. Environmental governance: participatory, multi-level - and effective? Environ. Policy Gov. 19, 197-214.

Newig, J., Kvarda, E., 2012. Participation in environmental governance: legitimate and effective? In: Hogl, K., Kvarda, E., Nordbeck, R., Pregernig, M. (Eds.), Environmental Governance. The Challenge of Legitimacy and Effectiveness. Edward Elgar, Cheltenham. 
Raitio, K., 2011. New institutional approach to collaborative forest planning on public land: methods for analysis and lessons for policy. Land Use Policy 29 (2), 309-316.

Rauschmeyer, F., Berghöfer, A., Omann, I., Zikos, D., 2009. Examining processes or/and outcomes? Evaluation concepts in European governance of natural resources. Environ. Policy Gov. 19, 159-173.

Schanz, H., 2002. National forest programmes as discursive institutions. For. Policy Econ. 4 (4), 269-279.

Secco, L., Pettenella, D., Gatto, P., 2011. Forestry governance and collective learning process in Italy: likelihood or utopia? For. Policy Econ. 13, 104-112.

Secco, L., Da Re, R., Pettenella, D.M., Gatto, P., 2013. Why and how to measure forest governance at local level: a set of indicators. For. Policy Econ. http://dx.doi.org/ 10.1016/j.forpol.2013.07.006.

Seo, M., Creed, W.E.D., 2002. Institutional contradictions, praxis, and institutional change: a dialectical perspective. Acad. Manag. Rev. 27 (2), 222-247.

Shannon, M., 2006. Participation as social inquiry and social learning. Schweiz. Z. Forstwes. 157 (10), 430-437.

Suda, M., 2002. Der Förster zwischen Fremd-und Selbstbild. In: Bayr. Staatsforstverwaltung (Ed.), 250 Jahre Bayerische Staatsforstverwaltung. Rückblicke, Einblicke, Ausblicke (München).
Suda, M., Binder, F., Wagner, K., Himmler, D., Arzberger, M., 2013. Projektbericht: INTERREG IVa Projekt: Schutzwaldplattformen und -foren in Tirol und Bayern, unpublished project report, Technische Universität München (TUM) and Bavarian State Institute of Forestry (LWF).

Süß, M., 2011. Bergwaldbewirtschaftung: Probleme-Konzepte-Lösungen. LWFaktuell, 84, pp. 4-5.

van der Arend, S., Behagel, J., 2011. What participants do. A practice-based approach to public participation in two policy fields. Crit. Policy Stud. 5 (2), 169-186.

Wagner, K., 2006. Schöner, forstlicher, ökonomischer!? Die politische Landschaft nach der Forstreform in Bayern. AFZ-Der Wald, p. 569.

Wagner, K., Arzberger, M., Himmler, D., 2012. Projektbericht: Ergänzende Begleitung der Bergwaldoffensive (BWO), unpublished evaluation report, Technische Universität München (TUM).

Winkel, G., Sotirov, M., 2011. An obituary for national forest programs? Analyzing and learning from the strategic use of 'new modes of governance' in Germany and Bulgaria. For. Policy Econ. 13, 143-154. 